\title{
The Diagnostic Facility of Tc-99m DTPA Clearance Method in the Long Term Follow-up of Improvement of Amiodarone-Induced Lung Damage
}

\section{Tc-99m DTPA Klirens Yönteminin Amiodaron'un Indüklediği Akciğer Hasarının Uzun Dönem Takibinde Tanısal Gücü}

Zehra Pınar Koç', Pelin Özcan Kara', Mukadder Çalıkoğlu²

\begin{abstract}
Amiodarone-induced lung damage (AILD) is a welldefined and important side effect of this drug which is challenging to diagnose with the classic morphological imaging methods. Although amiodarone is an efficient antiarrhythmic agent, there can be severe side effects, including lung damage. Previous observations have demonstrated that the technetiumlabeled diethylenetriamine pentaacetate (Tc-99m DTPA) clearance method is an accurate imaging modality in AILD. A 58-year-old male patient who used amiodarone as an antiarrhythmic agent presented with severe dyspnea but conventional computed tomography imaging revealed nothing diagnostic. Tc-99m DTPA clearance imaging was performed for the diagnosis and long-term follow-up of AILD after cessation of treatment. This case report describes the presence of AILD and long-term follow-up results of improvement using the Tc-99m DTPA clearance method.
\end{abstract}

Key words: Amiodarone, lung, toxicity, DTPA, clearance.

\section{Özet}

Amiodaronun tetiklediği akciğer hasarı (ATAH) bu ilacın doz kısıtlayıcı önemli bir yan etkisi olup tanısı klasik morfolojik yöntemlerle zordur. Amiodaron önemli bir antiaritmik ilaç olsa da ciddi yan etkileri olup bunlardan birisi de akciğer hasarıdır. Daha önceki gözlemler, Tc-99m DTPA klirensi hesaplanmasının bu akciğer hasarını göstermede doğru bir yöntem olduğunu göstermiştir. Elli sekiz yaşında erkek hasta, antiaritmik ilaç olarak amiodaron kullanmaktaydı. Hasta dispne yakınması ile geldi ancak konvansiyonel BT sonucu tanısal bir bulgu vermedi. ATAH tanısı ve ilacın kesilmesinden sonra uzun dönem takibinde Tc-99m DTPA görüntüleme yöntemi kullanıldı. Bu olgu sunumu, Tc-99m DTPA klirensinin ATAH tanısı ve uzun dönem tedavi takibinde yeterli bir metod olduğunu göstermektedir.

Anahtar Sözcükler: Amiodaron, akciğer, toksisite, DTPA, klirens.

$\begin{array}{ll}\text { 'Department of Nuclear Medicine, Mersin University, Mersin, Tur- } & \text { 'Mersin Üniversitesi Tıp Fakültesi, Nükleer Tıp Anabilim Dalı, } \\ \text { key } & \text { Mersin } \\ \text { 2Department of Respiratory Medicine, Mersin University, Mersin, } & { }^{2} \text { Mersin Üniversitesi Tıp Fakültesi, Göğüs Hastalıkları Anabilim } \\ \text { Turkey } & \text { Dalı, Mersin }\end{array}$

Submitted (Başvuru tarihi): 17.09.2018 Accepted (Kabul tarihi): 26.11.2018

Correspondence (iletişim): Zehra Pınar Koç, Department of Nuclear Medicine, Mersin University, Mersin, Turkey

e-mail: zehrapinarkoc@gmail.com 
Amiodarone is indicated in several cardiac diseases, and particularly those that lead to rhythm problems. However, there are several side effects of this drug, one of which is amiodarone-induced lung damage (AILD), a doselimiting adverse effect. The only treatment method for AILD is cessation of the therapy. Generally, this adverse effect is observed with a certain dose and duration of therapy. Morphological imaging methods cannot differentiate this entity from other causes of interstitial lung disease; thus, several functional imaging modalities have been proposed as a mean to distinguish this condition. One of the best methods to illustrate AILD is technetiumlabeled diethylenetriamine pentaacetate (Tc-99mm DTPA) clearance, which has been shown to demonstrate both the decrease in clearance half times (T1/2) during treatment and impairment a short time after the termination of treatment (1). To the best of our knowledge, this is the first report in the literature to show long-term results of Tc-99m DTPA clearance.

\section{CASE}

A 58-year-old male patient presented at the hospital with a history of an operation for mitral valve disease, and diagnoses of asthma and arrhythmia. He was in treatment with several drugs, including Coumadin, furosemide, and amiodarone. The patient reported experiencing severe dyspnea and cough after the start of amiodarone therapy. A contrast-enhanced thorax computed tomography (CT) image revealed only nonspecific findings of bronchial disease. Tc-99m DTPA clearance was performed in order to investigate the possibility of AILD. The patient received $1110 \mathrm{MBq}$ (30 mCi) Tc-99m DTPA via an aerosol delivery system (Venti-Scan III; Biodex Medical Systems, Inc., Shirley, NY, USA) in 2.5 cc solution for 3 minutes. A dynamic study consisting of 10 one-minute frames was then acquired. Data analysis was performed by an experienced nuclear medicine technologist and regions of interest were identified covering both lungs in anterior and posterior projection data, time activity curves were generated by the workstation, and the T1/2 were calculated (Figure 1a). The patient's T1/2 was 43 minutes, which supported the diagnosis of AILD. Three months after cessation of amiodarone treatment, the $\mathrm{T} 1 / 2$ increased to 68 minutes, which was consistent with recovery (Figure $1 \mathrm{~b}$ ). The patient's Tc-99m DTPA clearance improved significantly after termination of amiodarone use and the symptoms faded.

\section{DISCUSSION}

Although amiodarone is an essential drug in the treatment of several cardiac diseases, important adverse effects may be observed. However, it is not easy to discriminate AILD from primary disease- related symptoms. Typically, diagnostic imaging methods are required, as morphological imaging cannot reliably differentiate this entity. Thus, several radionuclide imaging methods have been proposed. The diagnostic facility of Tc-99m DTPA inhalation scintigraphy and aerosol clearance value was compared with the first imaging method, gallium-67 scintigraphy and the authors observed that it might provide the means for improved early-stage diagnosis (1). In a previous experimental study, the mean $\mathrm{T1} / 2$ values of Tc- $99 \mathrm{~m}$ DTPA patients were determined to be significantly increased compared with a control group, and the researchers concluded that this imaging method might indicate the degree of lung damage (2). The pathological mechanism illustrated by Tc-99m DTPA scintigraphy is the increased capillary permeability related to the drug side effect. The degree of injury to the lung depends on direct toxic effects and immunological indirect effects $(2,3)$. Early treatment can provide for complete recovery (4). Research has also demonstrated significantly higher T1/2 measurements in a severe exposure group (2).

lodine 123 metaiodobenzylguanidine and a lung retention index were also found to be effective in the determination of AILD in an experimental study examining that method and Tc-99m DTPA, and while both were successful, Tc-99m DTPA has the advantage of a lower cost (5). Another study comparing Tc-99mm DTPA lung scintigraphy with Tc-99m hexamethylpropyleneamine oxime (HMPAO) scintigraphy showed that although DTPA clearance decreases with cessation of use of the culprit drug, the pulmonary uptake in HMPAO remains (6). There are several other side effects of the amiodarone treatment, notably to the liver. Although Tc-99m HMPAO uptake in the lungs has been demonstrated to increase in proportion to the AILD, associated liver toxicity may complicate lung uptake. Furthermore, HMPAO uptake may initially be greater in smokers. 

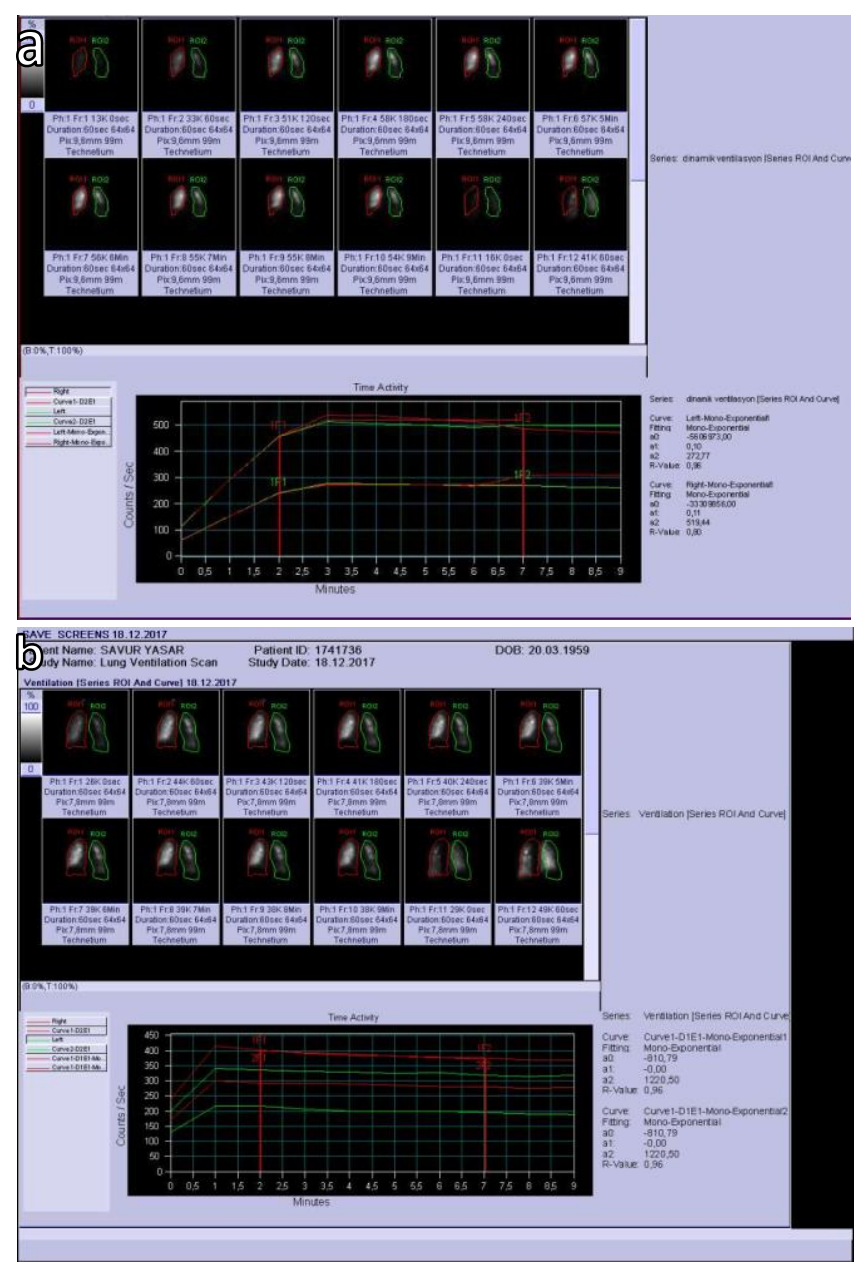

Figure 1a and b: The Tc-99m DTPA scintigraphy images of a patient with anamnesis of amiodarone treatment and new onset dyspnea at the diagnosis and several months after cessation of the treatment; a) The sequential anterior projection Tc-99m DPTA inhalation dynamic lung ventilation images in for the 10 minute imaging time. Additionally, the time activity curves corresponding to the region of interests in the determined areas in the dynamic images and quantitative analysis results of the lungs before treatment and b) after the long term cessation of the treatment with the same methodology showing the prolonged retention time of the radiopharmaceuticals in the lungs (increased clearance time) and improvement of the clearance after cessation of the treatment

Although there are limited data about the diagnosis of this dose-limiting side effect, among the current diagnostic methods, Tc-99m DTPA lung scintigraphy appears to be most reliable. DTPA clearance is a simple, costeffective, and accessible method to diagnose AILD and demonstrate recovery after the cessation of the drug therapy.

The diagnostic facility of the DTPA clearance method in the determination of AILD, as well as several other scintigraphic methods, have been used to demonstrate this side effect of amiodarone use. DTPA clearance can demonstrate short-term improvement in the lungs after the cessation of amiodarone use. For the first time, however, this case report shows that a DTPA clearance study might also indicate long term recovery results. The present report underlines the importance of functional imaging in the determination of AILD, as it can provide information regarding subtle changes at the tissue level that are not visible with conventional imaging.

\section{CONFLICTS OF INTEREST}

None declared.

\section{AUTHOR CONTRIBUTIONS}

Concept - Z.P.K., P.Ö.K., M.Ç.; Planning and Design Z.P.K., P.Ö.K., M.Ç.; Supervision - Z.P.K., P.Ö.K., M.Ç.; Funding - Z.P.K., P.Ö.K., M.Ç.; Materials - Z.P.K., P.Ö.K., M.Ç.; Data Collection and/or Processing - Z.P.K., P.Ö.K., M.Ç.; Analysis and/or Interpretation - Z.P.K., P.Ö.K., M.Ç.; Literature Review - Z.P.K., P.Ö.K., M.Ç.; Writing - Z.P.K., P.Ö.K., M.Ç.; Critical Review - Z.P.K., M.Ç., P.Ö.K.

\section{YAZAR KATKILARI}

Fikir - Z.P.K., P.Ö.K., M.Ç.; Tasarım ve Dizayn - Z.P.K., P.Ö.K., M.Ç.; Denetleme - Z.P.K., P.Ö.K., M.Ç.; Kaynaklar - Z.P.K., P.Ö.K., M.Ç.; Malzemeler - Z.P.K., P.Ö.K., M.Ç.; Veri Toplama ve/veya iş̧leme - Z.P.K., P.Ö.K., M.Ç.; Analiz ve/veya Yorum - Z.P.K., P.Ö.K., M.Ç.; Literatür Taraması - Z.P.K., P.Ö.K., M.Ç.; Yazıyı Yazan Z.P.K., P.Ö.K., M.Ç.; Eleştirel İnceleme - Z.P.K., M.Ç., P.Ö.K.

\section{REFERENCES}

1. Dirlik A, Erinc R, Ozcan Z, Atasever A, Bacakoglu F, Nalbantgil S, et al. Technetium-99m-DTPA aerosol scintigraphy in amiodarone induced pulmonary toxicity in comparison with Ga-67 scintigraphy. Ann Nucl Med 2002; 16:477-81. [CrossRef]

2. Durmus-Altun G, Altun A, Sami Salihoglu $Y$, Altaner $S$, Berkada S, Ozbay G. Value of technetium-99m diethyltriamine pentaaceticacid radioaerosol inhalation lung scintigraphy for the stage of amiodarone-induced pulmonary toxicity. Int J Cardiol 2004; 95:193-7. [CrossRef]

3. Martin WJ 2nd, Rosenow EC 3rd. Amiodarone pulmonary toxicity. Recognition and pathogenesis (Part 2). Chest 1988; 93:1242-8. [CrossRef]

4. Limper, A.H, Rosenow, E.C III. Drug-induced pulmonary disease. in: J.F Murray, J.A Nadel (Eds.) Text Book of Respiratory Medicine. 3rd ed. W.B. Saunder Company, Philadelphia; 2000: 1971-84.

5. Durmuş-Altun G, Altun A, Aktas RG, Salihoglu YS, Yigitbasi NO. Use of iodine-123 metaiodobenzylguanidine 
scintigraphy for the detection of amiodarone induced pulmonary toxicity in a rabbit model: a comparative study with technetium-99m diethyltriaminepenta acetic acid radioaerosol scintigraphy. Ann Nucl Med 2005; 19:21724. [CrossRef]
6. Kaya GK, Ozdogan O, Guneri S, Tamc B, Durak H. Tc99m HMPAO scintigraphy in amiodarone-induced acute lung toxicity: comparison with Tc-99m DTPA inhalation scintigraphy. Clin Nucl Med 2006; $31: 697-700$. [Cross$\underline{\text { Ref] }}$ 